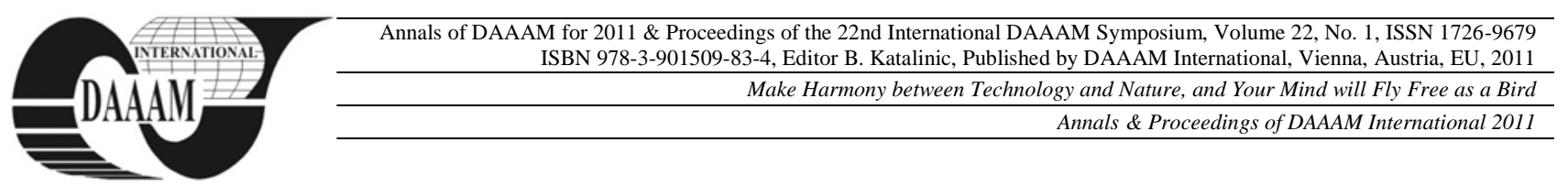

\title{
MOTIVATION OF WORKERS AS A FACTOR OF IMPROVING THE QUALITY OF BUSINESS
}

\author{
HERMAN, V[ilim] \& PETRICEVIC, A[nton]
}

\begin{abstract}
The purpose of this paper is to show how motivation of workers brings success and work satisfaction at their workplace. The research included 135 workers aged 25-65 years (men were included more in the older age group and women in the middle age group). The majority of respondents had secondary education and were employees of public administration. The results show that the motives which bring success at workplace and work satisfaction include better technical equipment of work places in public services, as well as financial bonuses, desire for personal promotion, further professional training and pleasant working atmosphere.

Key words: motivation, success, productivity, technical equipment, professional training
\end{abstract}

\section{INTRODUCTION}

The motivation of workers has become a subject of contemporary research management in order to create organizations that can be competitive in the market at this turbulent time. It is assumed that work performance depends on the worker's ability, as well as on motivation. The worker will work diligently and achieve excellent results if motivated.

There are various theories of motivation such as:

- Theory of values proposed by McClelland

- Theory of needs proposed by Maslow

- Theory of external influences and expectations.

A worker will perform better if he/she is motivated to work. If the worker, rather than being motivated, works in conditions that are uncertain, opaque, humiliating, unfair, he/she will experience acute lack of respect and feel the need to leave the work place, or more precisely the manager. If we want workers to be successful and to do well in their jobs, they must be occasionally motivated to work and encouraged. In addition, they should be given some autonomy in their jobs.

The first issue of this vast research area is what constitutes the motive. The Croatian Encyclopaedic Dictionary defines motivation as "that thing that moves us to an activity". When applied to work motivation, the question is "What motivates the worker to do the work well?"

Looking back through the work of some significant authors we can see that the working motive for Taylor was money, while Mayo talked about some other motives (e.g., humane relation to the worker).

Maslow said that physiological needs (such as the need for food) have the maximum power of motivation, as they come before the needs for security, social needs, the need for selfesteem, self-actualization, etc.

McClelland's work motivation was linked to childhood and adolescence, postulating that a man who as a child always had to put away his toys, had to go unaccompanied to school and independently cross the road, later achieved better results in the workplace. At the same time, not relying solely on this type of childhood independence, McClealland introduced a training programme for low-motivated workers, which has been giving excellent results.
Nowadays people work 40 hours per week or 1,600 hours per year, which amounts to approximately 65,000 hours in a lifetime. Without motives as key drivers it is questionable whether people would be able to work for so long and even earn their retirement.

\section{THE RESEARCH ON MOTIVATION}

The aim of our study was to examine the relationship between job satisfaction and achieving better company performance, and the exclusion of everything that might be a demotivating factor.

Our survey involved 135 respondents. Among them there were 50 men $(37.04 \%)$ and 85 women $(62.96 \%)$. The average age of respondents was 43.37 years, with a standard deviation of 10.03 years. The median value was 60 years. The youngest respondent was aged 25 and the oldest 65 , so the range of variation was 40 years. Half of the respondents were older than 36 years and younger than 52 years which means that the value of interquartile was 16 years. Since the coefficient of variation was $23.12 \%$, it can be concluded that the distribution of respondents by age is characterized by the degree of variability that cannot be considered small. The average age of male and female respondents differed slightly, while the median values were the same. The samples were dominated by the respondents with secondary school, and behind them came the respondents with post-secondary education.

Most of our respondents were employed in public services. The sample included 11 respondents who performed managerial functions at the time of the survey. Within the study the subjects were asked to answer questions related to motivation as follows:

-I think that properly and pleasantly decorated work space contributes significantly to the motivation for work

-I think that better technical equipment in the work space contributes significantly to the motivation for work

-I believe that financial stimulus (higher wages) significantly increases the motivation

-I believe that additional benefits (official mobile phone, company car) can significantly affect motivation

-I think that holidays paid by the employer contribute significantly to motivation

-I think that regular annual physical examination, whose costs are borne by the employer, has a significant impact on motivation

-I believe that part-ownership in the institution would significantly influence motivation

-I think that training possibilities provided and encouraged by the employer have a significant impact on motivation

-I think that the desire for personal growth significantly affects the motivation

-I think that an encouraging work team (fellow employees) and a pleasant working environment significantly affect the motivation

-I believe that unsubstantiated stories (gossip) in the work environment adversely affect the motivation 
-I believe that kind and sympathetic management significantly affects motivation

-I believe that informal contacts (meetings) with the managers have a significant effect on motivation

-I believe that working in a mobbing-free environment contributes significantly to the motivation

-I think that the worker is more motivated if working in one shift

-I think that the biggest motivation for work is accomplished during the first shift

-I think that worker motivation is lowest in the third shift

-I think that the biggest motivation is achieved at the beginning of the week

-I think that the biggest motivation is achieved at the end of the week

-I think that employee motivation is highest when not supervised directly, or when they are free to do the job as they see fit

-I believe that workers are more motivated when they are explained the purpose and objective of the work to be done

-I believe that workers would be more motivated if they were allowed to perform work at home (when possible)

-I believe that workers are more motivated when they have flexible working hours

-I believe that motivation is higher in workers who have a safe and secure workplace, and are not afraid of being made redundant

-I think that a reduction of working time, e.g. by one hour would increase motivation to work

-I believe that private problems can significantly reduce motivation.

The respondents ranked their responses on an ordinary scale which consisted of the following 5 grades:

-Strongly disagree (1),

-Mostly disagree (2),

-Neither agree nor disagree (3),

-Generally agree (4),

-Strongly agree (5).

On average, the respondents expressed the highest level of agreement with the claim that financial stimulus (higher wages) significantly increases motivation. The average grade of more than 4.5 was given to the claim that better technical equipment in the work space contributes significantly to the motivation. Median value of 5 was calculated for the following variables:

- I think that better technical equipment in the work space contributes significantly to the motivation for work

- I think that an encouraging work team (fellow employees) and a pleasant working environment significantly affect motivation -I believe that working in a mobbing-free environment significantly contributes to motivation.

The results of Mann-Whitney test showed statistically significant differences in these attitudes of male and female employees:

-I think that properly and pleasantly decorated work space contributes significantly to motivation,

-I think that the desire for personal growth significantly affects motivation

-I think that encouraging work team (fellow employees) and a pleasant working environment significantly affect motivation

-I believe that unsubstantiated stories (gossip) in the work environment adversely affect the motivation

-I believe that working in a mobbing-free environment contributes significantly to motivation

In all these cases, higher values of arithmetic mean and median were calculated for female employees.
For employees of younger age groups it has been noted that their motivation to perform better is significantly affected by:

- Better technical equipment in the workplace

- Paid vacations or winter vacations by their employer

- Possibility of further professional training

- Working team that drives one forward (fellow employees)

- Pleasant work environment

According to the results of Mann-Whitney test, there are significant differences in the attitudes of employees who exercise managerial functions as regards the claim "I believe that informal contacts (meetings) with the managers have a significant effect on motivation".

\section{CONCLUSION}

This paper sought to show how much satisfaction in the workplace, loyalty to the institution in which the worker is employed, neat work space, technical equipment of the institution, financial bonuses, different benefits (company car, official mobile phone, paid holidays, further professional training, good working atmosphere in the vertical between the worker-manager as well as the horizontal (colleagues at work) affect motivation in the workplace. It is noted that motives which produce positive effects are not the same for every working environment or for all individuals, groups, and professions.

However, the conclusion is that satisfaction is an essential factor that contributes to the positive behaviour of workers. If workers are exposed to stress or conflict at work or in their families, or in the wider community, overall satisfaction is diminished. As an example we can quote a statistic relating to the workforce in the European Union, i.e. the fact that stress present in the workplace (a survey of 285 EU citizens) resulted in the loss of millions of hours worked (or expressed in money it costs millions of Euros per year). Our survey indicates that even a small attempt at motivation contributes to increased business efficiency, although some authors view motivation in a negative light, considering it to be a covert way of increased exploitation of workers.

\section{REFERENCES}

Antic, M. (2009). Sociology of work and professional ethics, a manual for students, a collection of lectures, Civil Engineering, Zagreb

Denny, R. (2000). motivated for success-management techniques for greater achievements, M.E.P. Consult, Zagreb

Gladwell, M. (2008). Outliers: The Story of Success, Little, Brown and Company, New York, Boston, London

Hiam, A. (1999). Streetwise motivating \& rewarding employees: new and better ways to inspire your People, Adams Media, Avon, MA, USA

Croatian Encyclopaedic Dictionary (2002), Novi Liber, Zagreb

Jambrek, I., Penić, I. (2008). Human resource management in the enterprise-the human factor, Motivation of employees as the most important factors of success of business enterprises, Proceedings Faculty of Law, University of Rijeka, No. 2

Thomas, Kenneth W. (2000). Intrinsic motivation on work, Berretta-Koehler Publishers, San Francisco

Ziglar, Z. (2007). and more than a good life, Library ML, V.B.Z., Zagreb

http://ivonica.blogspot.com/2011/04/zadaci-menadzera-umotiviranju-ljudi.html (13.04.2011)

http://www.poslovniforum.hr/management/motivacijsketehnike.asp(13.04.2011.)

http://josipmikulic18.blogspot.com(10.04.2011.) 